\title{
Phenotyping of Tianma-Stimulated Differentiated Rat Neuronal B104 Cells by Quantitative Proteomics
}

\author{
Husvinee Sundaramurthi ${ }^{a}$ Arulmani Manavalan ${ }^{a, b}$ \\ Umamaheswari Ramachandran $^{\mathrm{a}, \mathrm{b}}$ Jiang-Miao Huc Siu Kwan Sze ${ }^{\mathrm{a}}$ \\ Klaus Heese ${ }^{a, b}$ \\ ${ }^{a}$ School of Biological Sciences, and ${ }^{b}$ Institute of Advanced Studies, Nanyang Technological University, Singapore; \\ 'Kunming Institute of Botany, Chinese Academy of Science, Kunming, China
}

\section{Key Words}

iTRAQ technology $\cdot$ Neural cell adhesion molecule $1 \cdot$

Neurodegenerative diseases • Tianma

\begin{abstract}
Gastrodia elata blume (tianma) is a traditional Chinese herb often used in the treatment of convulsions, headaches, and hypertension. Although interest in neuronal-related actions of tianma is increasing, minimal studies have been conducted to determine its specific effects on neuronal cells. This study was designed to examine the effects of tianma on the metabolism in differentiated neuroblastoma cells using the isobaric tag for relative and absolute quantitation (iTRAQ) technology. Stimulation of these cells with tianma caused changes in the expression of 38 proteins that were subsequently classified according to their physiological functions and association with neurodegenerative diseases. We identified six proteins with altered functional activities in neurodegenerative disease states that were modulated by tianma: triosephosphate isomerase (Tpi1), peptidyl-prolyl cis-trans isomerase A (Ppia), neural cell adhesion molecule 1 (Ncam1), ubiquitin carboxyl-terminal hydrolase isozyme L1 (Uchl1), septin-2 (Sept2) and heat shock protein 90 (Hsp90aa1). We
\end{abstract}

postulate that tianma mediates its neuroprotective effects via upregulation of Ncam1, Hsp90aa1, Tpi1 and Ppia while downregulating Sept 2 and Uchl1. These changes in protein expression aid in the restoration of the intracellular environment to a metabolically balanced state, promoting cell survival. Based on these observed data, we conclude that tianma has therapeutic potential, especially for neurodegenerative diseases.

Copyright $\odot 2011$ S. Karger AG, Basel

\section{Introduction}

Neurodegenerative diseases disrupt the functional activity of the central nervous system. These diseases are characterized by large-scale extracellular or intracellular protein deposits and misfolded protein aggregation, consequently causing a disruption in normal cellular metabolic and functional processes. As the disease advances, the buildup of misfolded proteins becomes so diverse that the various enzymes recruited for protein refolding are overwhelmed $[1,2]$. In addition, there is a further reduction in the competency of these enzymes as their activities are obliterated by the disease progression, thus accelerat-

\section{KARGER}

Fax +41613061234 E-Mail karger@karger.ch www.karger.com

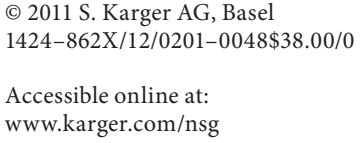

School of Biological Sciences, Department of Molecular and Cell Biology

Nanyang Technological University, 60 Nanyang Drive

Singapore 637551 (Singapore)

Tel. +65 6316 2848, E-Mail Klaus.Heese@ rub.de 
ing cell death. These cumulative factors ultimately lead to extensive brain degeneration $[3,4]$. The limited regenerative capacity of neuronal cells, confined to their specific niches, also further complicates cell replacement [5].

It has also been currently observed that there has been an escalation in the number of patients with neurodegenerative diseases such as Alzheimer's (AD), Parkinson's (PD), Huntington's diseases and amyotrophic lateral sclerosis due to the increasingly aging population [6-8]. Thus, together with the inadequate efficacy of existing treatment options and the adverse side effects of drugs, an increasing number of researchers have turned to alternative herbal medicine as a form of prophylaxis or cure for neurodegenerative diseases.

Traditional Chinese Medicine (TCM) has been given a lot of attention in recent years. In Asian countries, TCM, which involves the use of naturally available herbs, has been medicinally used for centuries due to its low risk of undesirable side effects. The dry orchid tuber of Gastrodia elata blume, more commonly known as 'tianma', is one such herb that is gathering interest in the treatment of neuronal diseases. It has been described by the Chinese Pharmacopoeia as an analgesic that can be used in the treatment of dizziness, hypertension, convulsion, epilepsy, vertigo and stroke [9-11]. Studies have reported that tianma has antioxidant, anti-inflammatory, anti-angiogenic properties $[12,13]$ in addition to possessing neuroprotective effects [14-16]. In one study conducted by Mishra et al. [17], mice stimulated with tianma showed improved cognitive functions and learning capacity. Based on these studies, tianma's neuroprotective roles and its ability to enhance learning and memory capabilities [13] have highlighted its potential as a therapeutic agent for neurodegenerative diseases.

To date, numerous new pharmacological properties of tianma are coming to light; however, most of these studies are disease specific. Protein profiling experiments have yet to be performed to determine the effect of tianma stimulation in the cellular proteome. Such experiments will allow us to understand the basic mechanisms through which tianma elicits its therapeutic actions. In this study, we investigated the effect of tianma stimulation on differentiated rat neuronal B104 cells using isobaric tag for relative and absolute quantitation (iTRAQ)based shotgun quantitative proteomics [18]. We found that upon tianma stimulation of neuronal cells, expression levels of several proteins were modified. Significantly, we discovered proteins related to neurodegenerative diseases having altered expression as well. Hence, we extrapolate that tianma has neuroprotective functions and it may improve disease pathology by restoring the functional activities of these proteins and attaining homeostasis for cell survival in disease-affected neuronal cells.

\section{Materials and Methods}

\section{Materials}

Cell culture media and supplements were bought from Gibco (Invitrogen, Carlsbad, Calif., USA); materials and reagents for SDS-PAGE (Sodium Dodecyl Sulfate-Polyacrylamide Gel Electrophoresis) were from Bio-Rad (Bio-Rad Laboratories, Hercules, Calif., USA). Reagents for biochemical experiments were purchased from Sigma-Aldrich (St. Louis, Mo., USA) unless otherwise stated. The iTRAQ ${ }^{\mathrm{TM}}$ Reagent Multi-Plex kit containing the iTRAQ reagents was bought commercially (Applied Biosystems, Foster City, Calif., USA). The procedure followed was a modified version of the manufacturer's protocol. The rhizome of G. elata (tianma) was collected from Zhaotong City, China and was provided by Dr. Jun Zhou (Kunming Institute of Botany, Chinese Academy of Science, Yunnan, China).

\section{Cell Culture}

B104 neuroblastoma cell line (American Type Culture Collection, Manassas, Va., USA) was cultured in 10-mm cell culture dishes (Greiner Bio-One GmbH, Frickenhausen, Germany) containing complete Dulbecco's Modified Eagle Medium (DMEM, Invitrogen). The composition of the media included DMEM plus GlutaMAX ${ }^{\mathrm{TM}}-1$ (4.5 g/l D-glucose and $110 \mathrm{mg} / \mathrm{l}$ sodium pyruvate), $10 \%$ fetal bovine serum (FBS, Invitrogen) and $1 \times$ antibiotic-antimycotic (Invitrogen). The cultures were maintained in a $37^{\circ} \mathrm{C}$ humidified incubator with $95 \%$ air and $5 \% \mathrm{CO}_{2}$. Differentiation of $\mathrm{B} 104$ cells involved the addition of retinoic acid (RA), final concentration of $20 \mu \mathrm{M}$, to the culture medium [19-21].

\section{Tianma Preparation}

Tianma was dissolved in deionized water to yield a final stock concentration of $100 \mathrm{mg} / \mathrm{ml}(0.36 \mathrm{~g}$ of powdered tianma in $3.6 \mathrm{ml}$ deionized water). The mixture was boiled and at regular intervals, mixed using the thermomixer comfort (Eppendorf, Hamburg, Germany) for $1 \mathrm{~h}$. Following this, the mixture was centrifuged at $16,000 \mathrm{~g}$ at $25^{\circ} \mathrm{C}$ for $10 \mathrm{~min}$. The supernatant was collected and filtered through a syringe-filter with a pore size of $0.25 \mu \mathrm{m}$ (Acrodisc ${ }^{\circledR}$ membrane filter, Pall Corporation, Singapore).

\section{Tianma Stimulation}

B104 cells were seeded in five poly-D-lysine (PDL)-coated sixwell plates (Becton Dickinson, San Jose, Calif., USA) at about 20\% confluency per well. Experiments were performed twice, with each set repeated six times. Controls were treated only with the solvent. The cells were allowed to attach and divide for $20 \mathrm{~h}$, after which RA was added to all experimental plates to promote neuronal differentiation. The media were changed once every 3 days and images were captured via an inverted microscope (Nikon Eclipse TE2000, Chiyoda-ku, Tokyo, Japan) every $24 \mathrm{~h}$ for 6 days. At the start of the 7th day in culture, B104 cells were stimulated with tianma to a final concentration of $1 \mathrm{mg} / \mathrm{ml}$ per well according to previous reports [17] for $30 \mathrm{~h}$, and subsequently images were captured before proceeding with cell lysis. 


\section{Cell Lysate Preparation}

All steps were performed on ice. Cell lysis buffer (ice cold) was prepared with $2 \%$ SDS, $0.5 \mathrm{M}$ triethyl ammonium bicarbonate buffer (TEAB), 1 Complete ${ }^{\mathrm{TM}}$ protease inhibitor cocktail tablet (Roche, Mannheim, Germany) and 1 PhosSTOP phosphatase inhibitor cocktail tablet (Roche). The wells were washed with icecold phosphate-buffered saline (PBS) twice to remove debris and dead cells. $100 \mu \mathrm{l}$ of cell lysis buffer was added to each well, and using a cell scraper (Greiner Bio-One) the attached cells were collected (six wells with same experimental conditions were pooled together). The pooled cell lysate was subjected to a quick spin and sonicated for $1 \mathrm{~min}$ (Vibra Cell ${ }^{\mathrm{TM}}$ ultrasonic processor, Jencon, Leighton Buzzard, UK) at an amplitude of $30 \mathrm{~W}$ and a pulse ( $3 \mathrm{~s}$ on and $6 \mathrm{~s}$ off). The cell lysate samples were centrifuged at $16,000 \mathrm{~g}$ at $4^{\circ} \mathrm{C}$ for $1 \mathrm{~h}$; supernatant was collected and stored at $-20^{\circ} \mathrm{C}$ until further use. The protein concentration was quantified by a 2-D Quant kit (Amersham, Piscataway, N.J., USA) according to the manufacturer's protocol.

\section{ITRAQ Protocol}

Sample Preparation - Acetone Precipitation

Each sample condition had $600 \mu \mathrm{g}$ of total protein lysate transferred to a new tube. Six volumes of $100 \%$ acetone chilled to $-20^{\circ} \mathrm{C}$ were added to each tube and vortexed thoroughly at regular intervals. The tubes were incubated overnight at $-20^{\circ} \mathrm{C}$, and the following day vortexed and centrifuged at $16,000 \mathrm{~g}$ for $30 \mathrm{~min}$ to pellet down all proteins. The supernatant was discarded and the pellets were disturbed and washed in $500 \mu \mathrm{l}$ of $90 \%$ acetone chilled to $-20^{\circ} \mathrm{C}$. Subsequently, the tubes were centrifuged at $16,000 \mathrm{~g}$ for $20 \mathrm{~min}$ and the supernatant discarded. The washed pellets were allowed to air-dry at room temperature (RT) for 15 min, then dissolved in $100 \mu \mathrm{l}$ of $200 \mathrm{~mm}$ TEAB and 2\% SDS and then incubated at $50^{\circ} \mathrm{C}$ for $5-10$ min with simple agitation using a thermomixer (Eppendorf). The tubes were centrifuged at $16,000 \mathrm{~g}$ for $30 \mathrm{~min}$. The supernatant was collected, and protein concentration was requantified using the 2-D Quant kit.

\section{SDS-PAGE and in-Gel Digestion}

Each sample had $200 \mu \mathrm{g}$ of acetone-precipitated proteins prepared (mixed with loading dye), denatured for $10 \mathrm{~min}$ in a thermo bath (Fine PCR, Seoul, Korea) and resolved up to $60 \%$ (fig. 1). The gels were washed twice with autoclaved Milli-Q Water (MQW) for 5 min each. Fixing solution (50\% methanol and 10\% acetic acid, $\mathrm{AcOH}$ ) was added until the gels were submerged and kept overnight on an SH30L reciprocating shaker (FINEPCR). The gels were then washed with MQW thrice for 15 min each. In-gel digestion was performed in a laminar flow hood (Gelman, Singapore). The gels were diced into $1-2 \mathrm{~mm}$ pieces and transferred into tubes. $5 \mathrm{ml}$ of $25 \mathrm{mM}$ TEAB in $50 \%$ Acetonitrile (ACN) buffer was added to the tubes, vortexed and left at RT for $10 \mathrm{~min}$ after which buffer was discarded and the step repeated four times. Finally, $80 \% \mathrm{ACN}$ in $20 \mathrm{mM}$ TEAB was added, vortexed, and the tubes were left at RT for $10 \mathrm{~min}$. The supernatant was discarded and the sample tubes were left to air-dry for $30 \mathrm{~min}$.

\section{Reduction, Alkylation, Trypsin Digestion and Extraction}

Stock solutions of $200 \mathrm{~mm}$ tris (2-carboxyethyl) phosphine (TCEP) in HPLC water (J.T. Baker, Mallinckrodt, Inc., Phillipsburg, N.J., USA) and $200 \mathrm{mM}$ S-methyl methanethiosulfonate (MMTS) in isopropanol were prepared. $5 \mathrm{mM}$ of TCEP in $25 \mathrm{~mm}$
TEAB buffer was added to the dried gel pieces, vortexed and briefly spun before being incubated at $65^{\circ} \mathrm{C}$ for $1 \mathrm{~h}$ to allow a reduction reaction to take place. Following this, $10 \mathrm{mM}$ MMTS in $25 \mathrm{mM}$ TEAB buffer (tube was covered with aluminum foil) was added to gel pieces vortexed and briefly spun. The alkylation reaction was then allowed to proceed for $45 \mathrm{~min}$ in the dark at RT. The supernatant was removed and discarded. The gel pieces were again washed with $25 \mathrm{mM}$ TEAB in 50\% ACN buffer as described above. The gel was dehydrated by $100 \%$ ACN. Finally, the tubes were airdried for $30 \mathrm{~min}$. First, trypsin (4 $\mu \mathrm{g}$ of trypsin in $25 \mathrm{mM}$ TEAB) was added to each set of the gel pieces and incubated at $4^{\circ} \mathrm{C}$ for 15 min for proper rehydration. The tubes were spun shortly and incubated in a $37^{\circ} \mathrm{C}$ incubator overnight.

Subsequently, the tubes were spun briefly and the aqueous extract of the digested solution was collected. To the remaining gel pieces, $50 \% \mathrm{ACN}$ and $1 \% \mathrm{AcOH}$ was added, vortexed and incubated in a water bath sonicator for $30 \mathrm{~min}$. The supernatant was transferred and combined with the main sample tube. The extraction step was repeated 5 times. The trypsin-digested peptides were pooled together and dried completely in the SpeedVac (Concentrator 5301, Eppendorf) at $30^{\circ} \mathrm{C}$ and stored at $-20^{\circ} \mathrm{C}$.

Labeling of Peptides with iTRAQ Tags (4 plex)

Each iTRAQ reagent tubes (tags-114, 115, 116, 117) had $70 \mu \mathrm{l}$ of $100 \%$ ethanol added and vortexed thoroughly. The dried peptides were dissolved in $30 \mu \mathrm{l}$ of $500 \mathrm{mM}$ TEAB (dissolution buffer). Each iTRAQ tag was transferred to the respective peptide tubes and the tubes were incubated at RT for $2 \mathrm{~h}$ with gentle shaking (thermomixer). All samples were then combined and kept in the SpeedVac at $30^{\circ} \mathrm{C}$ to dry.

\section{Desalting}

The dried peptide samples were reconstituted in $500 \mu \mathrm{l}$ of $0.1 \%$ formic acid (FA) and kept in the water bath sonicator for $5 \mathrm{~min}$. 50 mg C18 cartridge (Sep-Pak ${ }^{\circledR}$ Vac C18 cartridges, Waters, Milford, Mass., USA) was conditioned thrice with $100 \%$ methanol pushed through at a rate of 2-3 drops per second via a syringe. The stationary phase was acidified three times with $0.1 \%$ FA following the same method as conditioning. The sample was loaded into the column and allowed to flow via gravitational force, and the flow-through was reloaded three times. Next, the sampleloaded column was desalted twice with $0.1 \%$ FA. Elution buffer $(75 \% \mathrm{ACN}+0.1 \% \mathrm{FA})$ was added, and using a syringe the buffer was pushed through the column and the sample was collected. This C18 desalting protocol was performed thrice with the desalting wash's solution and the flow-through combined together. The samples were pooled together and placed in the SpeedVac to dry and stored at $-20^{\circ} \mathrm{C}$.

\section{Electrostatic Repulsion-Hydrophilic Interaction \\ Chromatography}

Eight hundred $\mu \mathrm{g}$ of iTRAQ-labeled peptides were fractionated using PolyWAX LP weak anion-exchange column $(4.6 \times 200$ mm, $5 \mu \mathrm{m}, 300 \AA$; PolyLC, Columbia, Md., USA), within the Shimadzu HPLC system (Kyoto, Japan). The HPLC gradient used was composed of $100 \%$ buffer A ( $85 \% \mathrm{ACN}, 0.1 \% \mathrm{AcOH}, 10 \mathrm{mM}$ ammonium acetate, $1 \% \mathrm{FA})$ for $5 \mathrm{~min}, 0-36 \%$ buffer $\mathrm{B}(30 \% \mathrm{ACN}$, $0.1 \% \mathrm{FA}, \mathrm{pH} 3.0$ ) for $15 \mathrm{~min}$, and $36-100 \%$ buffer B for $25 \mathrm{~min}$, and finally $100 \%$ buffer B for $10 \mathrm{~min}$, running for a total of $1 \mathrm{~h}$ at a flow rate of $1.0 \mathrm{ml} \mathrm{min}{ }^{-1}$. A total of 29 fractions were collected 


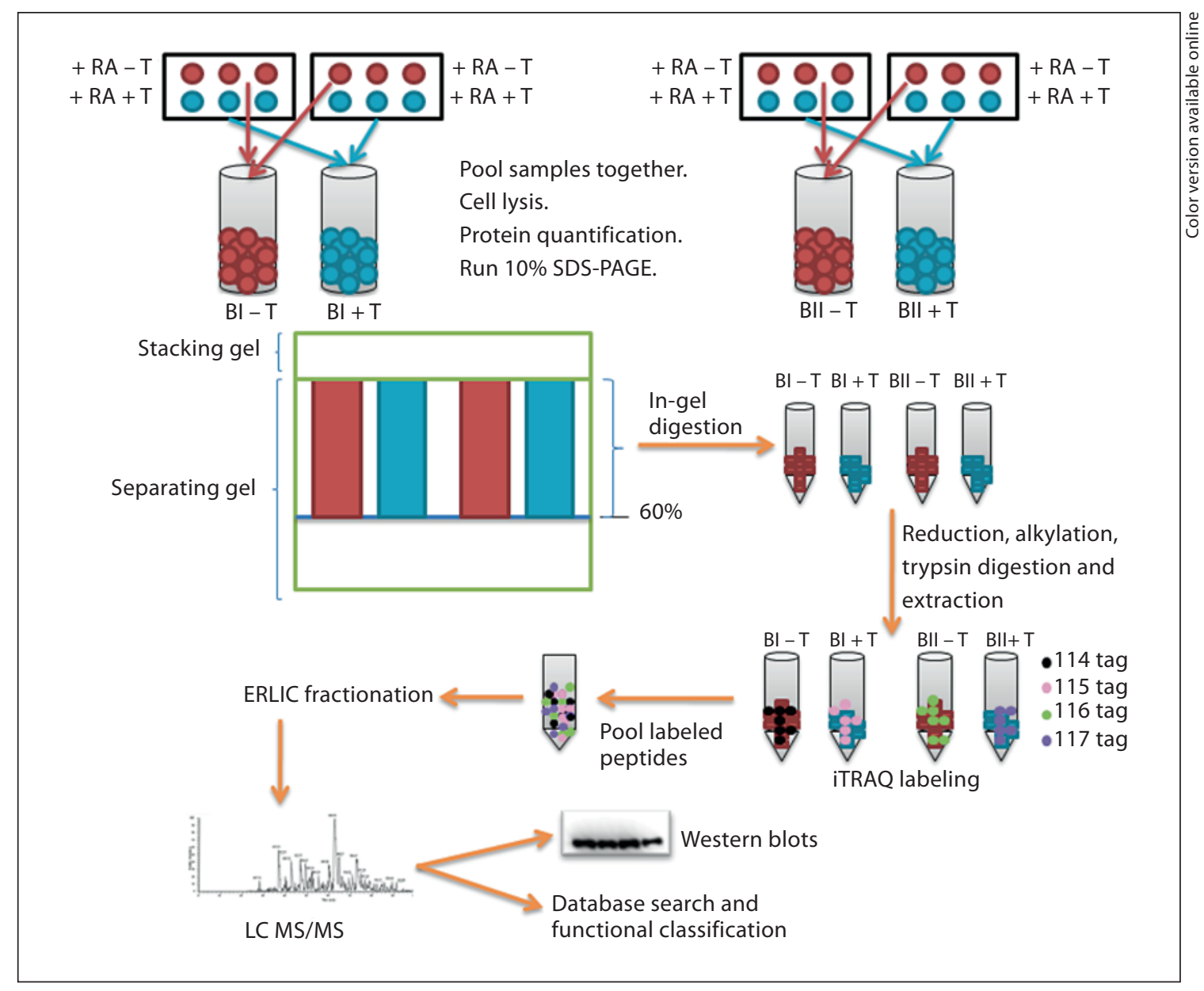

Fig. 1. Schematic diagram representing the procedures followed in this study. B104 rat neuroblastoma cells were cultured in PDLcoated six-well plates, differentiated using RA and stimulated with $1 \mathrm{mg} / \mathrm{ml}$ of tianma for $30 \mathrm{~h}$. The controls were differentiated with RA but not stimulated with tianma. Following tianma stimulation, the cells were lysed and protein extracts were acetone precipitated and quantified. These were then run in SDS-PAGE and subsequently digested. After that, the samples were labeled with iTRAQ tags $(114,115,116$ and 117), and sent for electrostatic repulsion-hydrophilic interaction chromatography (ERLIC) fractionation. The resulting samples were run in LC-MS/MS, and the obtained data were analyzed and quantified using ProteinPilot software and Western blots, respectively. BI = Batch I; BII = batch II; $\mathrm{T}=$ tianma. and were later reduced to 16 fractions by pooling of samples. The 16 sample tubes were kept in SpeedVac to dry completely. The dried peptides in each sample tube were reconstituted in $100 \mu \mathrm{l}$ $0.1 \%$ FA for liquid chromatography-tandem mass spectrometry (LC-MS/MS) analysis.

\section{LC-MS/MS Analysis}

The samples were analyzed thrice using a Q-Star Elite mass spectrometer (Applied Biosystems/MDS SCIEX) coupled with an online microflow HPLC system (Shimadzu). $30 \mu$ l of peptide mixture was injected and separated on a home-packed nanobored C18 column with a PicoFrit nanospray tip $(75 \mu \mathrm{m}$ i.d. $\times 15 \mathrm{~cm}$, 5 - $\mu \mathrm{m}$ particles; New Objective, Woburn, Mass., USA) for each analysis. The samples were separated at a constant flow rate of 30 $\mu \mathrm{l} / \mathrm{min}$ with a splitter achieving an effective flow rate of $0.3 \mu \mathrm{l} /$ min. Data acquisition was performed in the positive ion mode, with a selected mass range of $300-1,600 \mathrm{~m} / \mathrm{z}$, and peptide ions with +2 to +4 charge states were subject to MS/MS. The three most abundant peptide ions above 5 count threshold were selected for MS/MS and each selected target ion was dynamically excluded for $30 \mathrm{~s}$ with $30 \mathrm{mDa}$ mass tolerance. Automatic collision energy and automatic MS/MS accumulation were used to activate smart information-dependent acquisition. With maximum accumulation time being $2 \mathrm{~s}$, the fragment intensity multiplier was set to 20 . The relative abundance of the proteins in the samples was reflected by the peak areas of the iTRAQ reporter ions.

\section{Mass Spectrometric Data Analysis}

The data were acquired with the Analyst QS 2.0 software (Applied Biosystems/MDS SCIEX). Using ProteinPilot Software 
2.0.1, revision No.: 67476 (Applied Biosystems, Foster City, Calif., USA), protein identification and quantification were performed. The peptides were identified by the Paragon algorithm in the ProteinPilot software, and the differences between expressions of various isoforms were traced by Pro Group algorithm using isoform-specific quantification. The parameters used for database searching were defined as follows: (a) sample type: iTRAQ 4plex (Peptide Labeled); (b) cysteine alkylation: MMTS; (c) digestion: trypsin; (d) instrument: QSTAR Elite ESI; (e) special factors: none; (f) species: none; (g) specify processing: quantitate; (h) ID focus: biological modifications, amino acid substitutions; (i) database: concatenated 'target' (IPI rat; version 3.40; 40389 sequences and 20, 549, 266 residues) and 'decoy' (the corresponding reverse sequences); (j) search effort: thorough. Pro Group algorithm was used to automatically select the peptide for iTRAQ quantification, where the reporter peak area, error factor and $p$ value were calculated. Auto bias correction was carried out on the acquired data to remove variations imparted as a result of unequal mixing during the combination of the differently labeled samples. Then, data analysis and functional classification were conducted using online databases such as NCBI, UniProt, and Panther.

\section{Antibodies}

We used the following antibodies: anti-Ncam (neural cell adhesion molecule, 1:1,000, rabbit polyclonal; Santa Cruz Biotechnology Inc., Santa Cruz, Calif., USA), anti-Hsp90 $\alpha$ (heat shock protein $90 \alpha, 1: 1,000$, mouse monoclonal; Santa Cruz Biotechnology), anti-Vimentin (V9; 1:1,000, mouse monoclonal; Lab Vision Products, Thermo Fisher Scientific Inc., Fremont, Calif., USA), anti-Sept2 (Septin 2, 1:200, goat polyclonal; Santa Cruz Biotechnology), anti-histone H4 (1:3,000, rabbit monoclonal; Millipore Corporation, Billerica, Mass., USA), anti-cyclophilin A (peptidylprolyl cis-trans isomerase A, Ppia, 1:1,000, rabbit polyclonal; Abcam, Cambridge, UK) and anti-GAPDH (glyceraldehyde-3-phosphate dehydrogenase, 1:1,000, mouse monoclonal; Santa Cruz Biotechnology).

\section{Western Blot}

Twenty micrograms of each cell lysate sample was resolved by $10 \%$ SDS-PAGE at $0.02 \mathrm{~A}$ of constant current and transferred onto a nitrocellulose membrane $(0.22 \mu \mathrm{m}$; BioRad $)$ for $60 \mathrm{~min}$ at $0.12 \mathrm{~A}$ in a buffer containing $25 \mathrm{~mm}$ Tris, $192 \mathrm{~mm}$ glycine, $20 \%$ methanol, and $0.01 \%$ (wt/vol) SDS. The membrane was blocked for $2 \mathrm{~h}$ at RT with 3\% bovine serum albumin (BSA) in PBS with $0.1 \%$ Tween-20 (PBS-T). The membrane was washed three times in PBS-T for 15 min each, and incubated with a primary antibody (diluted in 3\% BSA in PBS-T) for $2 \mathrm{~h}$ at RT. The membranes were washed as before and incubated with an HRP-conjugated secondary antibody for $1 \mathrm{~h}$ at RT. The ECL-plus Western blot detection reagent (Amersham) was applied as substrate and the blots were developed using the LAS-4000 luminescent image analyzer (Fujifilm Life Science, Stamford, Conn., USA). GAPDH was used as the internal control to ensure equal loading of samples.

Western blot experiments were performed three times for statistical quantification and analyses $(n=3)$. Relative protein expression values represent the ratio of densitometric scores (GS800 Calibrated Densitometer and Quantity One quantification analysis software version 4.5.2; BioRad) for the respective Western blot products (mean \pm standard deviation, SD) using the GAPDH bands as a loading control.

\section{Results}

\section{Effect of Tianma Stimulation on Cell Morphology}

B104 rat neuroblastoma cells were differentiated using RA as described previously. After $30 \mathrm{~h}$ of tianma stimulation, we could not detect any obvious morphological changes in the B104 cells (fig. 2).

One possible reason is that the therapeutic activity mediated by tianma may occur at the metabolic level, but not at the morphological level. Hence, iTRAQ was performed on the cellular protein extracts in order to obtain a complete protein expression profile that can determine the effects of tianma at the molecular level.

\section{Proteomic Data by iTRAQ and Western Blot \\ Quantification}

All experiments were performed twice (BI and BII), with each set repeated six times. We used four samples (two unstimulated and two tianma-stimulated) to perform iTRAQ as 6 biological replicates (all done twice: BI and BII, thus total biological replicates $=12$ ). This was to ensure high confidence in the detection of proteins regulated by tianma. The quality of the dataset and instrumental reproducibility were then confirmed by comparing and combining three technical replicates [18] after the samples were labeled with 114, 115, 116 and 117 isobaric tags and processed in LC MS/MS.

Through iTRAQ, we identified a total of 2,980 proteins which we sorted based on an unused score of $\geq 1.3$ (that indicates a 95\% confidence level) and obtained 778 proteins. In order to verify that the protein samples were indeed from the whole cell proteome, the identified protein names were uploaded into JVirGel, a database software that creates a virtual 2-D gel [22]. The proteins were categorized based on their isoelectric point and molecular weight (fig. 3). The virtual 2-D gel image showed that the samples collected originated from the whole cell proteome as the spots in the gel were well dispersed.

We compared proteins from the two batches of experiments and found a total of 38 proteins that exhibited common trends in both experimental batches (online suppl. table 1, www.karger.com/doi/10.1159/000331492). 15 of these proteins were upregulated, and the remaining 23 proteins were downregulated, with the cutoff for upand downregulation predefined at 1.2 and 0.83 , respectively. We proceeded to use online databases (Panther, UniProt, and NCBI) to identify the functions of these proteins.

During the classification process, our objective was to identify proteins with roles in neurodegenerative dis- 


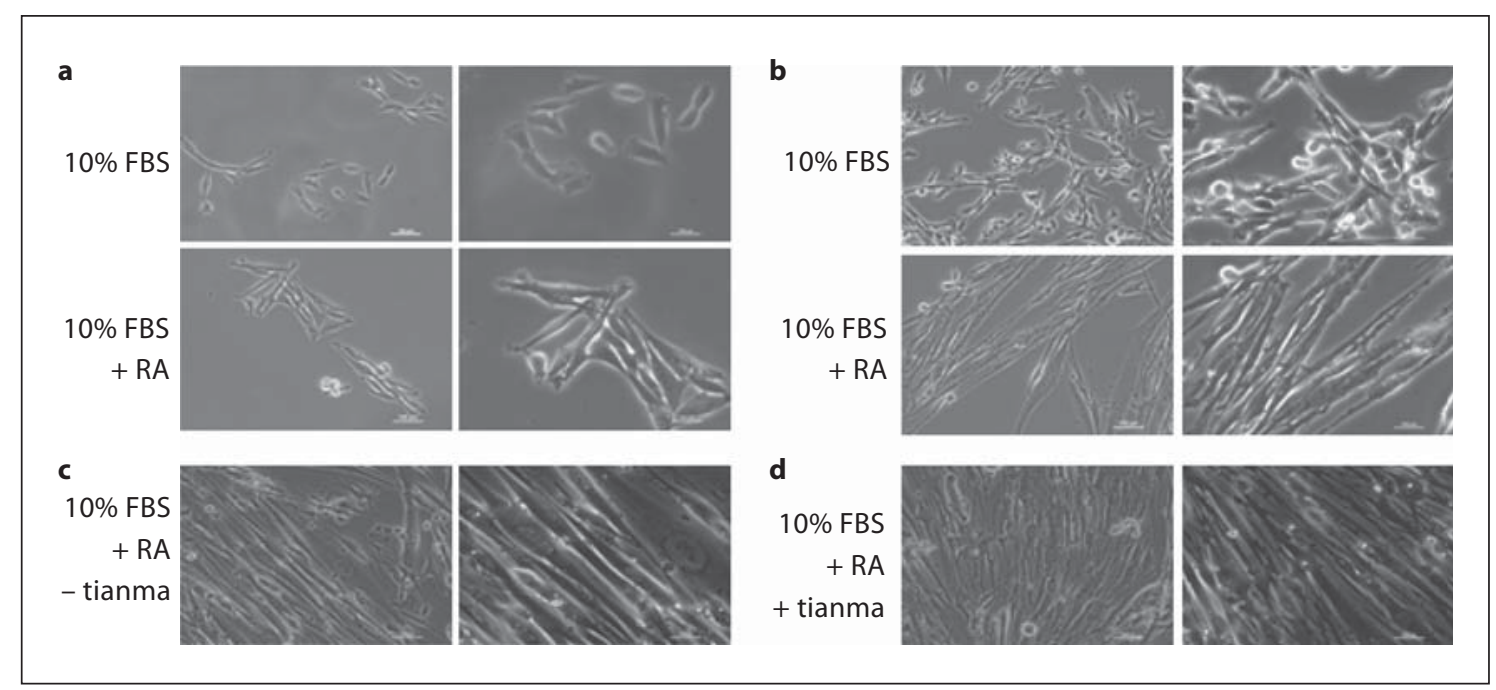

Fig. 2. B104 cells seeded and grown in PDL coated six-well plates. a Day 1: $24 \mathrm{~h}$ after RA treatment; top row: cells grown in 10\% FBS; bottom row: cells grown in $10 \%$ FBS and $20 \mu \mathrm{M}$ RA. b Day 3: $72 \mathrm{~h}$ after RA treatment; top row: cells grown in $10 \%$ FBS; bottom row: cells grown in $10 \%$ FBS and $20 \mu \mathrm{M}$ RA for $72 \mathrm{~h}$. c Day 7 : $144 \mathrm{~h}$ after RA treatment but before tianma stimulation. These images show that neurite outgrowth is initiated after $24 \mathrm{~h}$ of RA treatment, and prolonged treatment of cells with RA (144 h) allowed formation of extensive neural networks. d $30 \mathrm{~h}$ after $1 \mathrm{mg} /$ $\mathrm{ml}$ of tianma stimulation. Stimulation of B104 cells with tianma did not result in any visible morphological changes.

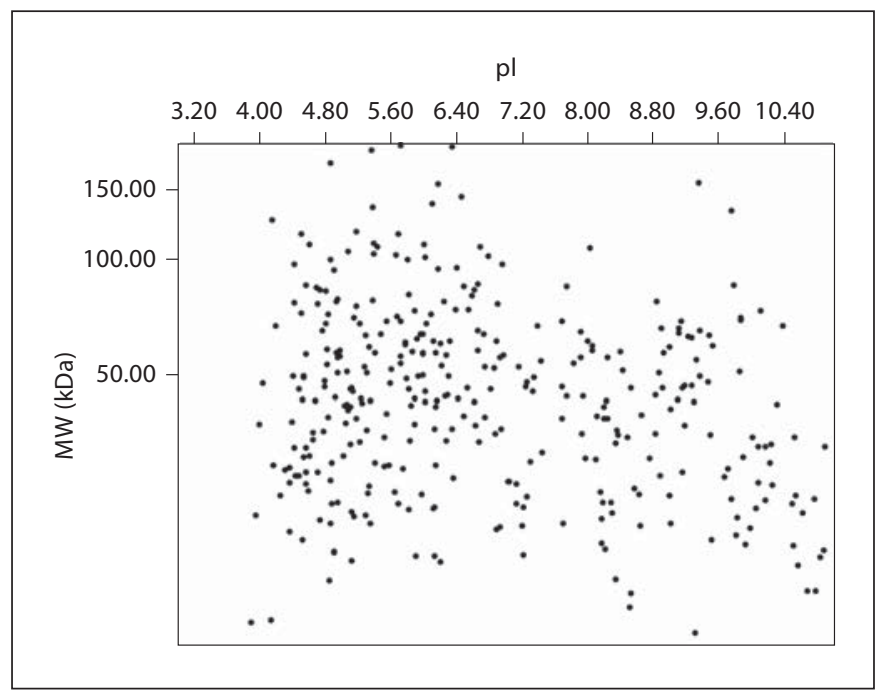

Fig. 3. Virtual 2-D gel image. The proteins identified by LC-MS/ MS were uploaded onto JvirGel, an online software used to create a 2-D gel image. This image confirmed that the cell lysis performed was adequate and the entire proteome within cells were extracted. $\mathrm{MW}=$ Molecular weight; $\mathrm{pI}=$ isoelectric point.

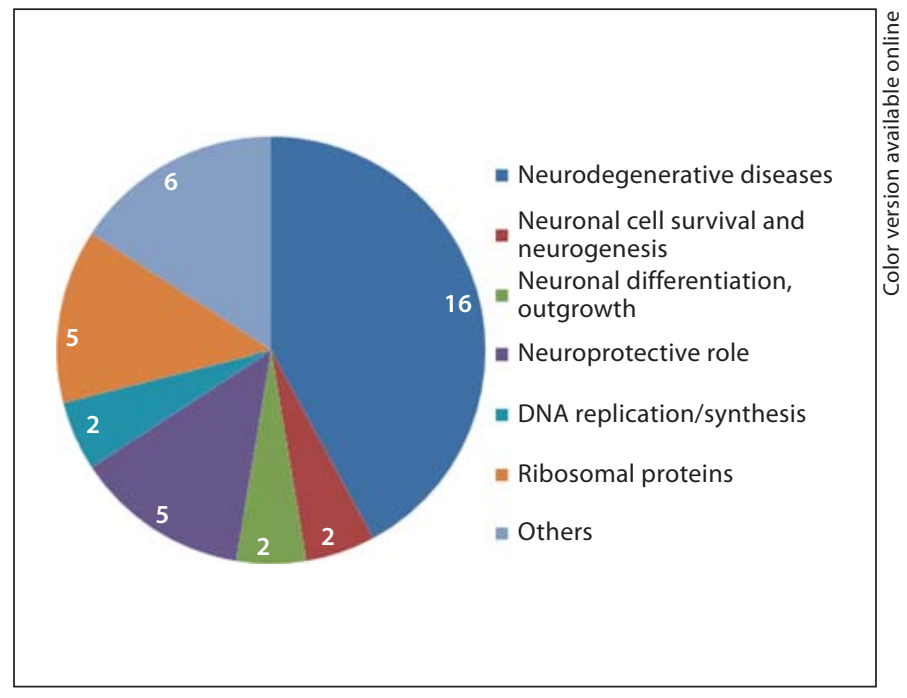

Fig. 4. Proteins classified into seven functional groups. The 38 proteins identified by iTRAQ were classified into seven groups, illustrating that the proteins affected by tianma have varied roles and are not specific to any single pathway. The number of proteins classified to each group is given in the pie chart. 


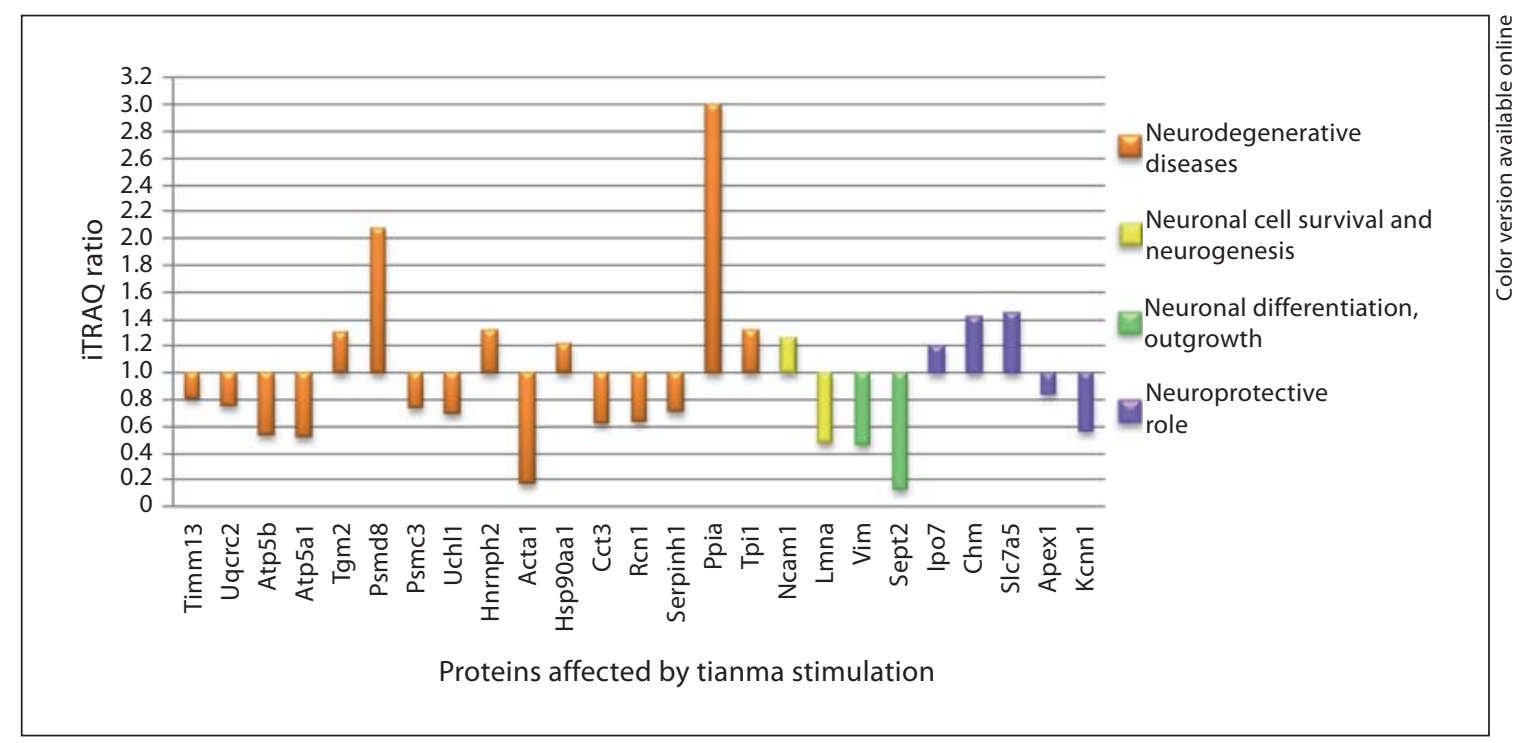

Fig. 5. Proteins with neuronal-related functions that were up- or downregulated upon tianma stimulation. The expressions of proteins with neuronal-related functions were up- or downregulated as a result of tianma stimulation of differentiated neuronal B104 cells. These proteins were classified into four groups. Values above 1.2 indicate upregulation, and values below 0.83 indicate downregulation of the proteins.

eases. Of these 38 proteins, 16 were implicated in neurodegenerative diseases, 2 were involved in neuronal cell survival and neurogenesis, 2 were involved in neuronal differentiation and outgrowth functions, 5 had neuroprotective roles, 2 had roles in DNA replication, 5 were ribosomal-related proteins and the remaining 6 had various enzymatic roles (fig. 4).

The 38 proteins were sorted out based on their functions, as shown in table 1. Proteins with roles in neurodegenerative diseases were also subcategorized into mitochondrial, proteasomal, chaperones and other proteins. In this group, 10 proteins, namely Timm13, Uqcrc2, Atp5a1, Atp5b, Psmc3, Uchl1, Cct3, Rcn1, Serpinh1 and Acta1, were found to be downregulated. The remaining 6 proteins, Hsp90aa1, Ppia, Tpil, Tgm2, Psmd8 and Hnrnph2, were upregulated.

Ncam1 and Lmna, both involved in neurogenesis and neuronal cell survival, were found to be up- and downregulated, respectively (fig. 5). Neuronal differentiation and outgrowth-related proteins, Vim and Sept2, were both downregulated. Proteins with neuroprotective roles, Ipo7, Chm and Slc7a5, were upregulated, while Apex1 and $\mathrm{Kcnn} 1$ were downregulated. The remaining proteins have important roles in DNA replication, ribosomal proteins or other functions (fig. 6). Many of these are part of multi-protein complexes or are involved in various meta- bolic functions, suggesting that the regulation of a diverse array of signaling pathways is dependent upon expression of these proteins.

Following the database search and classification of proteins, Western blots were performed on selected proteins to validate the iTRAQ values. Seven proteins, Hsp90aal, Ncam1, Sept2, Vim, Histlh4b, Ppia and GAPDH (fig. 7) were used for validation.

The Western blot images correlated with the iTRAQ values obtained. Notably, although the up- or downregulation of these proteins were not extensive in most cases, the level of protein expression may not necessarily correlate with its activity. Hence, a small increase in the protein expression can also lead to increased functional activity. GAPDH was used as an internal control to ensure equal loading of samples as its level was unchanged in the iTRAQ analysis.

\section{Discussion}

Tianma, a naturally occurring herb, has been gaining recognition as a potential therapeutic agent for neurodegenerative diseases due to its observed positive roles in disease-afflicted neuronal cells $[10,23]$. However, the effect of tianma at the proteome level has yet to be deter- 
Fig. 6. Effects of tianma stimulation on protein expression in differentiated neuronal B104 cells. The remaining proteins that did not have neuronal-related functions, but were found to be up- or downregulated by tianma stimulation were classified into three groups. The modulation of these protein levels may have a significant effect on both universal gene and protein expression. Values above 1.2 indicate upregulation and values below 0.83 indicate downregulation of the proteins.

Fig. 7. a Western blots used to validate iTRAQ data. Ncam1, Ppia and Hsp90aa1 levels increased upon tianma stimulation, while Sept2, Hist1h4b and Vim levels were reduced. The Western blots correlated with the iTRAQ values obtained. GAPDH was used as internal control. b Statistical evaluation of the Western blots. The Western blot experiments were performed three times for statistical evaluation ( $\mathrm{n}=$ 3). The relative protein expression corresponded to the ratio of densitometric scores for the respective Western blot products (mean $\pm \mathrm{SD}$ ) with the GAPDH bands used as reference.
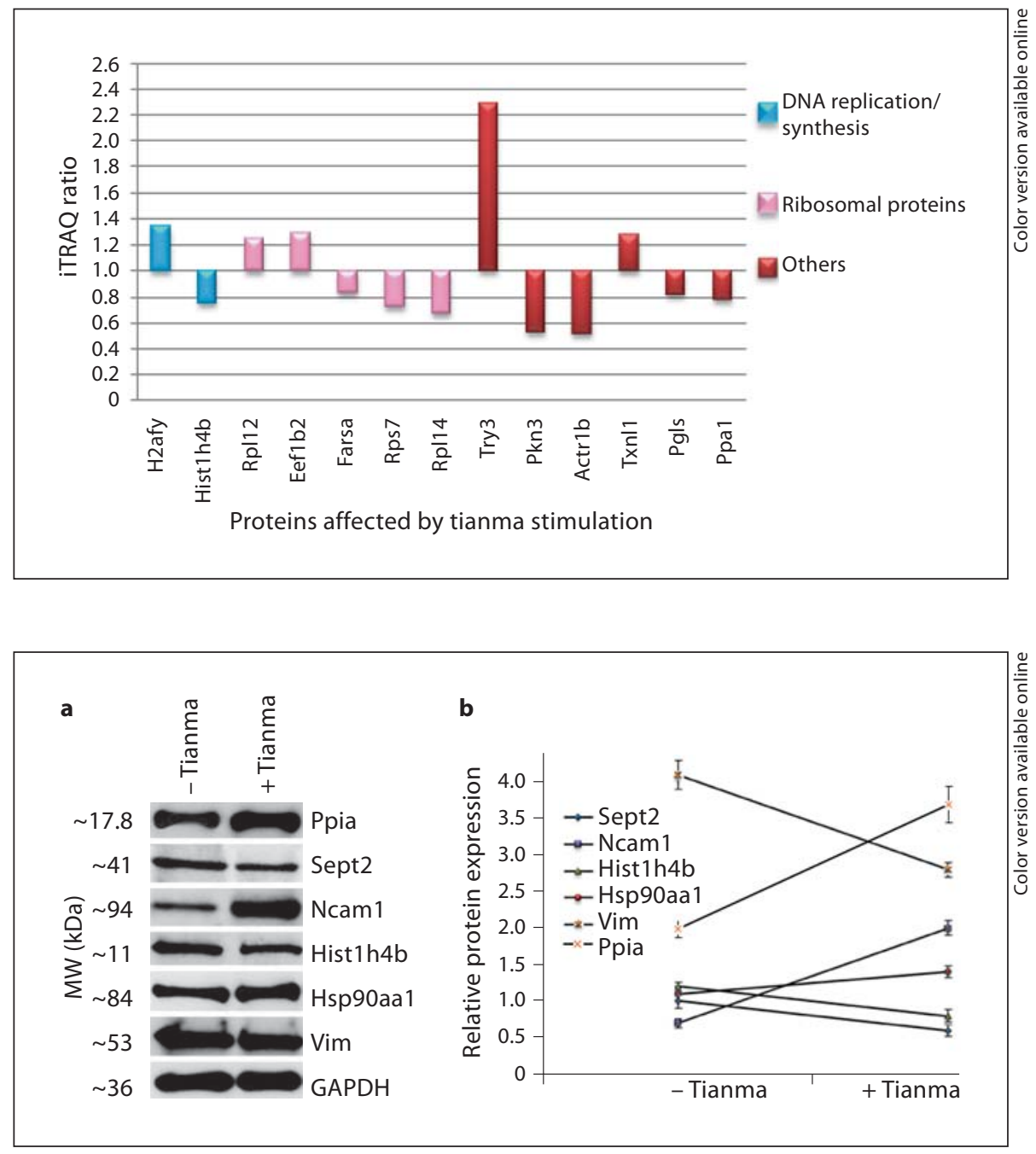

mined. Hence, with the utilization of iTRAQ technique to determine which proteins are regulated by tianma, we discovered 38 proteins (15 upregulated and 23 downregulated) with modified expressions. These were then categorized with respect to their physiological functions and association to neurodegenerative diseases.

Successively, six proteins with altered functions in neurodegenerative diseases were selected from the groups: Tpil, Ppia, Hsp90aal and Uchl1 (neurodegenerative diseases), Ncam1 (neuronal cell survival and neurogenesis) and Sept2 (neuronal differentiation and outgrowth). In the following sections, the specific functional roles of these proteins, their relevance to neuronal diseases and the consequences of their modified expressions will be discussed.

Proteome Analysis of Tianma-Stimulated Neurons

\section{Tpil and Ppia Activities Are Found to Be Reduced in} Neurodegenerative Diseases

Tpil (triosephosphate isomerase) is an enzyme used in glycolysis to convert dihydroxyacetone phosphate to glyceraldehyde-3-phosphate. It is crucial for cell survival as the loss of Tpil activity leads to an accumulation of methylglyoxal (MG) [24]. It is proposed that MG reacts with DNA and proteins, resulting in by-products such as advanced glycation end-products (AGEs) that impair the activity of these macromolecules and cell viability [25]. In $\mathrm{AD}$, Tpil proteins were found to be concentrated within microtubule-associated protein tau (Mapt) protein aggregates [26], resulting in the loss of Tpil activity and consequently, its neuroprotective functions. This may be a factor contributing to AD-related pathogenesis. 
Table 1. List of 38 proteins that were found to be affected by tianma stimulation in differentiated neuronal B104 cells

\begin{tabular}{|c|c|c|c|c|c|c|}
\hline Classification categories & Gene name & $\begin{array}{l}\text { Gene } \\
\text { symbol }\end{array}$ & $\begin{array}{l}\text { Protein } \\
\text { ID }\end{array}$ & $\begin{array}{l}\text { Number } \\
\text { of peptides } \\
(>95 \%)\end{array}$ & $\begin{array}{l}\text { iTRAQ } \\
\text { ratio }\end{array}$ & Protein localization \\
\hline \multicolumn{7}{|l|}{ Neurodegenerative diseases } \\
\hline Involved in disease pathway & $\begin{array}{l}\text { mitochondrial import inner membrane translocase } \\
\text { subunit Tim } 13\end{array}$ & Timm13 & P62076 & 1 & 0.74 & mitochondria \\
\hline Involved in disease pathway & cytochrome b-c1 complex subunit 2 , mitochondrial & Uqcrc2 & P32551 & 5 & 0.73 & mitochondria \\
\hline Involved in disease pathway & ATP synthase subunit beta, mitochondrial & Atp5b & P10719 & 110 & 0.49 & mitochondria \\
\hline Involved in disease pathway & ATP synthase subunit alpha, mitochondrial & Atp5a1 & P15999 & 127 & 0.42 & mitochondria \\
\hline Involved in disease pathway & transglutaminase $2, \mathrm{C}$ polypeptide & Tgm2 & Q6P6R6 & 13 & 1.24 & plasma membrane \\
\hline \multicolumn{7}{|l|}{ Proteasomal proteins } \\
\hline Involved in disease pathway & $\begin{array}{l}\text { proteasome (prosome, macropain) 26S subunit, } \\
\text { non-ATPase, } 8\end{array}$ & Psmd8 & Q3B8P5 & 1 & 3.22 & cytoplasm \\
\hline Involved in disease pathway & $26 \mathrm{~S}$ protease regulatory subunit $6 \mathrm{~A}$ & Psmc3 & Q63569 & 7 & 0.77 & cytoplasm \\
\hline Involved in disease pathway & ubiquitin carboxyl-terminal hydrolase isozyme L1 & Uchl1 & Q00981 & 2 & 0.62 & cytoplasm \\
\hline \multicolumn{7}{|l|}{ Chaperones } \\
\hline Prevent protein aggregation & heat shock protein HSP 90 alpha & Hsp90aa1 & P82995 & 107 & 1.21 & cytoplasm \\
\hline Prevent protein aggregation & T-complex protein 1 subunit gamma & Cct3 & Q6P502 & 8 & 0.69 & cytoplasm \\
\hline Stress response & reticulocalbin 1 (predicted), isoform CRA_a & Rcn 1 & D3ZUB0 & 1 & 0.72 & ER \\
\hline Stress response & serpin $\mathrm{H} 1$ & Serpinh1 & P29457 & 25 & 0.70 & ER \\
\hline \multirow[t]{2}{*}{ Chaperone binding protein } & peptidyl-prolyl cis-trans isomerase A & Ppia & P10111 & 55 & 2.14 & cytoplasm \\
\hline & triosephosphate isomerase & Tpil & P48500 & 10 & 1.59 & cytoplasm \\
\hline \multicolumn{7}{|l|}{ Others } \\
\hline Involved in disease pathway & heterogeneous nuclear ribonucleoprotein $\mathrm{H} 2$ & Hnrnph2 & Q6AY09 & 4 & 1.48 & nucleus \\
\hline Involved in disease pathway & actin, alpha skeletal muscle & Actal & P68136 & 114 & 0.43 & cytoplasm \\
\hline \multicolumn{7}{|c|}{ Neuronal cell survival and neurogenesis } \\
\hline & neural cell adhesion molecule 1 & Ncam1 & P13596 & 3 & 1.22 & plasma membrane \\
\hline & lamin-A & Lmna & P48679 & 45 & 0.53 & nucleus \\
\hline \multicolumn{7}{|c|}{ Neuronal differentiation, outgrowth } \\
\hline & vimentin & Vim & P31000 & 342 & 0.34 & cytoplasm \\
\hline & septin-2 & Sept2 & Q91Y81 & 13 & 0.25 & cytoplasm \\
\hline \multicolumn{7}{|l|}{ Neuroprotective role } \\
\hline Transport proteins & importin 7 (predicted) & Ipo7 & D4AE96 & 3 & 1.20 & cytoplasm, nucleus \\
\hline Transport proteins & $\begin{array}{l}\text { Rab proteins geranylgeranyltransferase } \\
\text { component A } 1\end{array}$ & Chm & P37727 & 1 & 1.39 & cytoplasm \\
\hline $\begin{array}{l}\text { Transport proteins, } \\
\text { neurotransmitters }\end{array}$ & large neutral amino acids transporter small subunit 1 & Slc7a5 & Q63016 & 1 & 1.37 & plasma membrane \\
\hline Repair DNA damage & DNA-(apurinic or apyrimidinic site) lyase & Apex1 & P43138 & 3 & 0.72 & nucleus \\
\hline Regulating excitability & $\begin{array}{l}\text { small conductance calcium-activated potassium } \\
\text { channel protein } 1\end{array}$ & Kcnn1 & P70606 & 1 & 0.64 & plasma membrane \\
\hline \multicolumn{7}{|l|}{ DNA replication } \\
\hline DNA binding & core histone macro-H2A.1 & H2afy & Q02874 & 1 & 1.27 & nucleus \\
\hline DNA binding & histone $\mathrm{H} 4$ & Hist1h4b & P62804 & 102 & 0.60 & nucleus \\
\hline \multicolumn{7}{|l|}{ Ribosomal proteins } \\
\hline Protein synthesis & $60 \mathrm{~S}$ ribosomal protein L12 (22 kDa) & Rpl12 & P23358 & 12 & 1.29 & cytoplasm \\
\hline Protein synthesis & eukaryotic translation elongation factor 1 beta 2 & Eef1b2 & B5DEN5 & 18 & 1.22 & cytoplasm \\
\hline Protein synthesis & phenylalanyl-tRNA synthetase alpha chain & Farsa & Q505J8 & 2 & 0.82 & cytoplasm \\
\hline Protein synthesis & $40 \mathrm{~S}$ ribosomal protein $\mathrm{S} 7$ & Rps7 & P62083 & 20 & 0.76 & mitochondria \\
\hline Protein synthesis & $60 \mathrm{~S}$ ribosomal protein $\mathrm{L} 14$ & Rpl14 & Q63507 & 13 & 0.44 & cytoplasm \\
\hline \multirow[t]{6}{*}{ Others } & cationic trypsin-3 & Try3 & P08426 & 2 & 1.74 & extracellular (secreted) \\
\hline & Pkn3 protein kinase N3 (uncharacterized protein) & Pkn3 & D3ZC07 & 9 & 0.62 & cytoplasm \\
\hline & ARP1 actin-related protein 1 homolog B (yeast) & Actr1b & B2RYJ7 & 6 & 0.56 & cytoplasm \\
\hline & thioredoxin-like protein 1 & Txnl1 & Q920J4 & 1 & 1.52 & cytoplasm \\
\hline & 6-phosphogluconolactonase & Pgls & P85971 & 3 & 0.80 & cytoplasm \\
\hline & pyrophosphatase (inorganic) 1 & Ppal & Q499R7 & 1 & 0.77 & cytoplasm \\
\hline
\end{tabular}

$\mathrm{ER}=$ Endoplasmic reticulum 


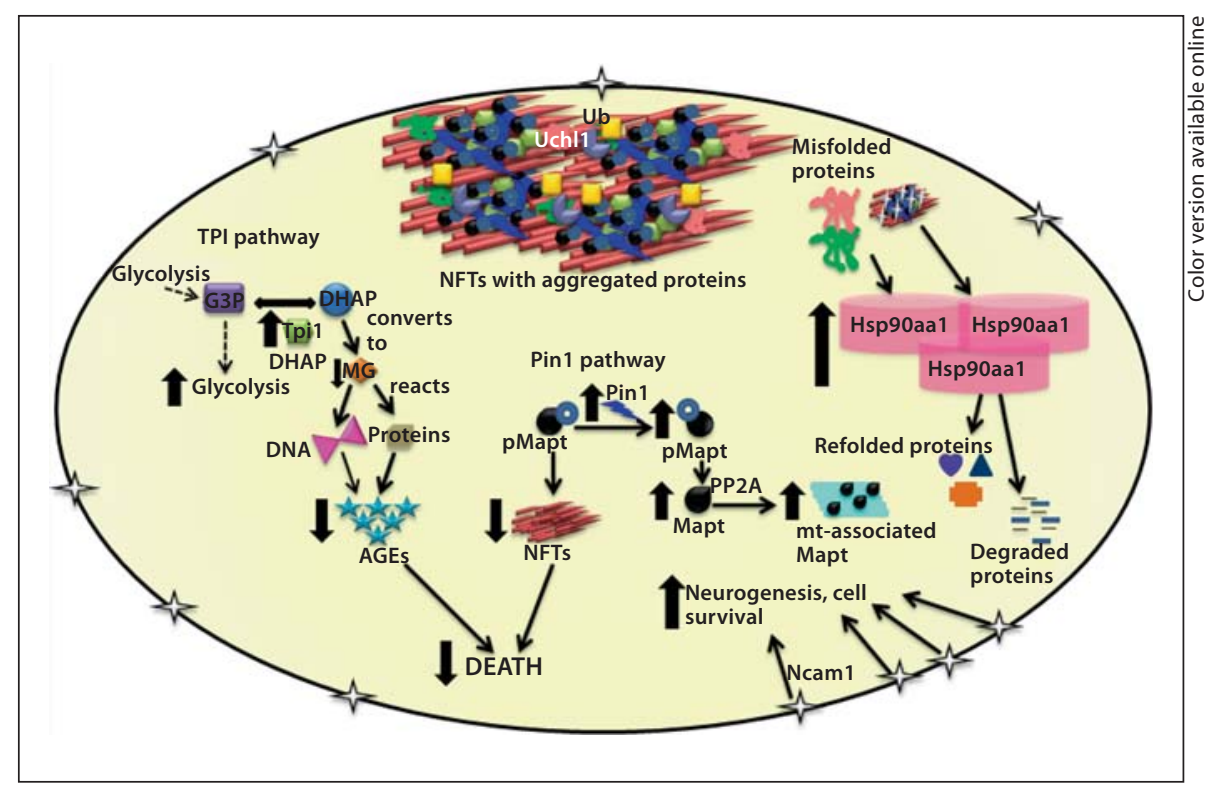

Fig. 8. Disease-afflicted neuronal cell after tianma stimulation. A neuronal cell that is afflicted with $\mathrm{AD}$ has protein aggregates deposited throughout the cytoplasm extensively due to the loss of Tpil and Pin1 activities. Loss of the Tpil activity leads to the generation of AGEs. Conversely, blocking the Pin1 pathway prevents Mapt from interacting with microtubules ( $\mathrm{mt}$ ) and instead, forms neurofibrillary tangles (NFTs). In both cases, the result is cell death. In addition, the levels of Uchl1 and ubiquitin (Ub) molecules are reduced as a result of accumulation within the protein aggregates. Besides the alteration in the levels of these proteins, Ncam 1 levels are increased to promote neurogenesis and cell survival. However, this surge in Ncam 1 levels remains inadequate to sustain cell survival due to the extensive modifications in the metabolic pathways within the cells. When these cells are stimulated with tianma, the levels of Tpil, Pin1 and Ncam1 increase and their functional activities within neurons are restored or augmented. This reduces cell death and increases the rate of neurogenesis. Hsp90aal levels are also increased, suggesting recovery of misfolded proteins, hence reducing the volume of protein deposits within the cells. Overall, tianma increases neurogenesis and prevents cell death. G3P = Glyceraldehyde-3-phosphate; DHAP = dihydroxyacetone phosphate; $\mathrm{PP} 2 \mathrm{~A}=$ the phosphatase activity of Pin1 that removes phosphate from phosphorylated Mapt (pMapt).
Ppia is from the family of peptidyl prolyl isomerase proteins [27]. There has not been any research done on Ppia in relation to neurodegenerative diseases. However, Ppia activities are found to be similar to Pin1 [28], which is a member of the same family that has been implicated in neurodegenerative diseases. Pin 1 has cis-trans isomerase and phosphatase activity that is necessary for its neuroprotective role. Pin1 elicits its neuroprotective role by interacting with phosphorylated Mapt proteins, inducing cis-trans isomerization. Subsequently, it removes the phosphate group from Mapt proteins via its phosphatase activity, thereby preventing phosphorylated Mapt accumulation and the formation of cytotoxic neurofibrillary tangles. Pin 1 also downregulates the production of toxic amyloid- $\beta(A \beta)$ peptides [29-31]. However, in AD, Pin1 accumulated within neurofibrillary tangles, leading to the loss of its activity $[28,32]$. Consequently, Mapt proteins remained hyperphosphorylated, and toxic $A \beta$ pep- tide level increased within the cells, resulting in an exacerbation of protein deposits [33]. Based on the functional similarities between Ppia and Pin1, it is possible that Ppia may also have neuroprotective roles with similar mechanism to that of Pinl.

As tianma upregulated the level of Tpil and Ppia, we hypothesize that treating $\mathrm{AD}$ with tianma may restore the functional activity of these proteins. This may reduce the levels of hyperphosphorylated Mapt proteins, protecting neurons from death and alleviating the clinical symptoms of $\mathrm{AD}$.

\section{Hsp90aal as a Protective Mechanism in \\ Neurodegenerative Diseases}

Molecular chaperones are a family of proteins that assist in the refolding of misfolded proteins to their native structure or shuttling proteins out for degradation [34, 35]. Research has been conducted on their potential use 
as therapeutic agents for neurodegenerative diseases [36, 37]. At an increased level of Hsp90aal (heat shock protein HSP 90-alpha), a member of the chaperone family, the formation of Mapt protein aggregates were reduced and the binding of Mapt with microtubules was augmented [36]. Hsp90aal also aids in the refolding of misfolded $\alpha$ synuclein, thereby protecting cells from Lewy bodies and possibly, the onset of $\mathrm{PD}[38,39]$.

Importantly, chaperone proteins usually do not work alone but form complexes with co-chaperones. These chaperone complexes are then involved in the process of refolding or marking the target proteins for degradation [34]. Interestingly, Pin1 associates with Hsp90aal as part of a complex [40]. It is postulated that Hsp90aal and associated proteins capture misfolded or phosphorylated Mapt proteins. Subsequently, Pin1 which is in a complex with the chaperone unit, will dephosphorylate the Mapt proteins, or alternatively, proteasomal-related proteins that are also associated with the complex will target the Mapt proteins for degradation [40-42]. This suggests that other members of the peptidyl prolyl isomerase family, such as Ppia, may also form interactions with molecular chaperones $[43,44]$.

Hence, upregulation of Hsp90aal by tianma may increase chaperone activity and the refolding of misfolded proteins, preventing the formation and accumulation of aggregates within the cells, and promotes normal cellular functions.

\section{Loss of Uchl1 Activity in Neurodegenerative Diseases}

The role of Uchll (ubiquitin carboxyl-terminal hydrolase isozyme L1) is to bind, sequester and prevent the degradation of mono-ubiquitin molecules [45]. Mono-ubiquitin molecules maintain cellular processes by eliminating unwanted materials via degradation through the ubiquitin-proteasomal system. However, in AD, Uchl1 and ubiquitin molecules were accumulated within the neurofibrillary tangles $[46,47]$. This could lead to a decrease in available ubiquitin molecules, and as a cumulative effect of decreased degradative capacity and accumulation of toxic materials within the internal environment, cell death ensues. The treatment of disease-afflicted cells with exogenous Uchll alleviated the detrimental effects caused by the loss of Uchll activity, indicating the importance of this protein for cell survival [48].

Interestingly, tianma stimulation resulted in decreased Uchll level, signifying that this in part could be a consequence of increased Tpil and Ppia levels. As these two proteins attenuate the formation of Mapt protein aggregates, the need for ubiquitin molecules and Uchl1 activ- ity is reduced. Additionally, as neurofibrillary tangle formation decreases, the sequestration of Uchll and ubiquitin molecules will also be reduced. Hence, the basal level of Uchll activity could be sufficient for maintaining cell survival.

\section{Sept2 Downregulation May Prevent Neurofibrillary}

\section{Tangle Formation}

Septins are a family of proteins with GTPase activity that serve a variety of functions in vesicle trafficking, cell division and actin cytoskeleton organization [49]. These proteins are capable of a wide range of activities through oligomerization and association with various proteins to form complexes. Hence, disruptions or alterations in their functions are detrimental to cellular function and integrity and will lead to diseases [50].

A member of the family, Sept2 (septin-2), interacted with Mapt proteins and accumulated within the neurofibrillary tangles in AD [51]. Overexpression of Sept2 also led to the formation of fibrous deposits within the cell cytoplasm. It is postulated that by interacting with Mapt proteins, Sept 2 may facilitate the formation of neurofibrillary tangles $[49,51]$. However, further research is required to determine the exact mechanism and role of Sept 2 in the interaction with Mapt proteins and the consequences on the formation of neurofibrillary tangles.

As tianma stimulation downregulated Sept2, we hypothesize that this reduces Sept2 interaction with Mapt proteins and thereby reduces the formation of neurofibrillary tangles.

\section{Ncam1 Plays a Pivotal Role during Neurogenesis}

Ncam1 (neural cell adhesion molecule 1) is involved in neurogenesis, neuronal development, neural regeneration, synaptic plasticity and cognitive functions [52]. The hippocampus of AD brains shows elevated levels of Ncam1, indicating that the brain has regenerative capacities upon the initiation of neurodegeneration [53]. Paradoxically, in $\mathrm{AD}$ and $\mathrm{PD}$, where large-scale cell death occurs, there is very low neuron renewal capacity. This can either be attributed to an insufficient turnover of neurons that sequentially impedes dead cell replacement or the decreased functional capacity of Ncaml due to an extensive formation of neurofibrillary tangles and disrupted internal environment.

When neurons expressing $A \beta$ peptides were treated with a synthetic peptide (FGL peptide) mimicking Ncaml's fibroblast growth factor receptor binding site, neurons also showed a reduction in neurotoxic effects mediated by A $\beta$ [54]. FGL peptide was discovered to act 
on the GSK3 $\beta$ pathway via protein kinase $\mathrm{C}$ and the phosphatidyl inositol-3 kinase signaling pathway to prevent cell death and increase cell survival rate $[54,55]$. It is highly possible that the neuroprotective effect of Ncam1 is also mediated by these two signaling pathways. Upon tianma stimulation, Ncam1 levels were increased. This represents a possibility to replace lost neurons and improve both memory and cognitive abilities in $\mathrm{AD}$ and $\mathrm{PD}$ patients through tianma treatment.

As such, we postulate the effect of tianma treatment on disease-afflicted neuronal cells (fig. 8).

Tianma reinstates Tpil and Pin1 activity, which aids in reducing cell death caused by accumulated AGEs, neurofibrillary tangles and $A \beta$ peptides. It also increases Hsp90aal levels, which refolds misfolded proteins and prevents their accumulation within the cytoplasm, hence alleviating the stress imposed on the cells by the deposits of protein aggregates. An increased level of Ncaml facilitates neurogenesis and cell survival, enabling the replacement of lost neurons and rescuing affected cells from death. Moreover, Sept 2 downregulation further reduces the formation of neurofibrillary tangles and protein aggregates.

Tianma treatment also resulted in the modulation of other proteins' levels, indicating that these proteins act in a concerted manner to modify the internal environment via the modulation of cell metabolic activities, which may then protect neuronal cells from death. Therefore, tian- ma's neuroprotective and therapeutic effect is not mediated by a single mechanism, but through a complex pathway in which the intracellular environment is modulated. From our study, we conclude that tianma is a promising therapeutic agent for both prevention and treatment of neurodegenerative diseases.

As this is a pilot study, it is imperative that the research be extended to in vitro and in vivo experiments (brain tissue samples and animal studies). Studies should also be conducted in systems (AD/PD mouse models) that mimic the various neurodegenerative disease states. This is important in light of the fact that internal environment differences exist despite similarities in pathological symptoms. Furthermore, phytochemical analysis of tianma will provide information on the specific chemical compounds that are involved in eliciting these observed reactions. Following these studies, the mechanisms through which the proteins modulated by tianma act to provide a therapeutic effect in neurodegenerative diseases can be elucidated.

\section{Acknowledgments}

We would like to thank Ms. Joan Poh-Lim Sim for her editorial assistance. This study was supported by the Institute of Advanced Studies, Nanyang Technological University.

\section{References}

1 Taylor JP, Hardy J, Fischbeck KH: Toxic proteins in neurodegenerative disease. Science 2002;296:1991-1995.

$\checkmark 2$ Soto C: Unfolding the role of protein misfolding in neurodegenerative diseases. Nat Rev Neurosci 2003;4:49-60.

- 3 Rodolfo C, Ciccosanti F, Giacomo GD, Piacentini M, Fimia GM: Proteomic analysis of mitochondrial dysfunction in neurodegenerative diseases. Expert Rev Proteomics 2010;7:519-542.

4 Hardy J, Orr H: The genetics of neurodegenerative diseases. J Neurochem 2006;97:16901699.

5 Kokovay E, Shen Q, Temple S: The incredible elastic brain: how neural stem cells expand our minds. Neuron 2008;60:420-429.

-6 Forman MS, Trojanowski JQ, Lee VM: Neurodegenerative diseases: a decade of discoveries paves the way for therapeutic breakthroughs. Nat Med 2004;10:1055-1063.
7 Prusiner SB: Shattuck lecture - neurodegenerative diseases and prions. N Engl J Med 2001;344:1516-1526.

8 Shulman JM, De Jager PL: Evidence for a common pathway linking neurodegenerative diseases. Nat Genet 2009;41:1261-1262.

$\checkmark 9$ Bulpitt CJ, Li Y, Bulpitt PF, Wang J: The use of orchids in Chinese medicine. JR Soc Med 2007; 100:558-563.

10 Kim HJ, Moon KD, Lee DS, Lee SH: Ethyl ether fraction of Gastrodia elata blume protects amyloid beta peptide-induced cell death. J Ethnopharmacol 2003;84:95-98.

-11 Huang NK, Chern Y, Fang JM, Lin CI, Chen WP, Lin YL: Neuroprotective principles from Gastrodia elata. J Nat Prod 2007;70: 571-574

12 Ahn EK, Jeon HJ, Lim EJ, Jung HJ, Park EH: Anti-inflammatory and anti-angiogenic activities of Gastrodia elata blume. J Ethnopharmacol 2007;110:476-482.
13 Ho SC, Ho YF, Lai TH, Liu TH, Su SY, Wu RY: Effect of tianma gouteng decoction with subtractive ingredients and its active constituents on memory acquisition. Am J Chin Med 2008;36:593-602.

-14 Kim HJ, Moon KD, Oh SY, Kim SP, Lee SR: Ether fraction of methanol extracts of Gastrodia elata, a traditional medicinal herb, protects against kainic acid-induced neuronal damage in the mouse hippocampus. Neurosci Lett 2001;314:65-68.

15 Huang NK, Lin YL, Cheng JJ, Lai WL: Gastrodia elata prevents rat pheochromocytoma cells from serum-deprived apoptosis: the role of the MAPK family. Life Sci 2004;75: 1649-1657.

16 An H, Kim IS, Koppula S, Kim BW, Park PJ, Lim BO, Choi WS, Lee KH, Choi DK: Protective effects of Gastrodia elata blume on $\mathrm{MPP}+$-induced cytotoxicity in human dopaminergic Sh-Sy5y cells. J Ethnopharmacol 2010;130:290-298. 
17 Mishra M, Huang J, Lee YY, See DKC, Lin X, $\mathrm{Hu}$ J-M, Heese K: Gastrodia elata modulates amyloid precursor protein cleavage and cognitive functions in mice. BioSci Trends 2011; 5:129-138.

18 Datta A, Park JE, Li X, Zhang H, Ho ZS, Heese K, Lim SK, Tam JP, Sze SK: Phenotyping of an in vitro model of ischemic penumbra by iTRAQ-based shotgun quantitative proteomics. J Proteome Res 2010;9:472-484.

19 Encinas M, Iglesias M, Liu Y, Wang H, Muhaisen A, Cena V, Gallego C, Comella JX: Sequential treatment of Sh-Sy5Y cells with retinoic acid and brain-derived neurotrophic factor gives rise to fully differentiated, neurotrophic factor-dependent, human neuronlike cells. J Neurochem 2000;75:991-1003.

-20 Jamsa A, Hasslund K, Cowburn RF, Backstrom A, Vasange M: The retinoic acid and brain-derived neurotrophic factor differentiated Sh-Sy5y cell line as a model for Alzheimer's disease-like tau phosphorylation. Biochem Biophys Res Commun 2004;319: 993-1000.

21 Ruiz-Leon Y, Pascual A: Induction of tyrosine kinase receptor $\mathrm{B}$ by retinoic acid allows brain-derived neurotrophic factor-induced amyloid precursor protein gene expression in human Sh-Sy5y neuroblastoma cells. Neuroscience 2003;120:1019-1026.

22 Hiller K, Schobert M, Hundertmark C, Jahn D, Munch R: JVirGel: calculation of virtual two-dimensional protein gels. Nucleic Acids Res 2003;31:3862-3865.

-23 Ojemann LM, Nelson WL, Shin DS, Rowe AO, Buchanan RA: Tian ma, an ancient Chinese herb, offers new options for the treatment of epilepsy and other conditions. Epilepsy Behav 2006;8:376-383.

24 Ahmed N, Battah S, Karachalias N, BabaeiJadidi R, Horanyi M, Baroti K, Hollan S, Thornalley PJ: Increased formation of methylglyoxal and protein glycation, oxidation and nitrosation in triosephosphate isomerase deficiency. Biochim Biophys Acta 2003; 1639:121-132.

25 Gnerer JP, Kreber RA, Ganetzky B: Wasted away, a drosophila mutation in triosephosphate isomerase, causes paralysis, neurodegeneration, and early death. Proc Natl Acad Sci USA 2006;103:14987-14993.

-26 Park SA, Park HW, Kim NH, Kim YH, Kwak MJ, Shin JS, Kim CW: Effects of tau on the activity of triose phosphate isomerase (TPI) in brain cells. Neurochem Int 2010;56:886892.

-27 Fanghanel J, Akiyama H, Uchida C, Uchida T: Comparative analysis of enzyme activities and mRNA levels of peptidyl prolyl cis/trans isomerases in various organs of wild type and pin1-/- mice. FEBS Lett 2006;580:32373245.

28 Lu KP, Finn G, Lee TH, Nicholson LK: Prolyl cis-trans isomerization as a molecular timer. Nat Chem Biol 2007;3:619-629.
29 Butterfield DA, Abdul HM, Opii W, Newman SF, Joshi G, Ansari MA, Sultana R: Pin1 in Alzheimer's disease. J Neurochem 2006 98:1697-1706.

30 Lu PJ, Wulf G, Zhou XZ, Davies P, Lu KP: The prolyl isomerase Pin1 restores the function of Alzheimer-associated phosphorylated tau protein. Nature 1999;399:784-788.

- 31 Pastorino L, Sun A, Lu PJ, Zhou XZ, Balastik M, Finn G, Wulf G, Lim J, Li SH, Li X, Xia W, Nicholson LK, Lu KP: The prolyl isomerase Pin1 regulates amyloid precursor protein processing and amyloid-beta production. Nature 2006;440:528-534.

32 Liou YC, Sun A, Ryo A, Zhou XZ, Yu ZX, Huang HK, Uchida T, Bronson R, Bing G, Li $\mathrm{X}$, Hunter T, Lu KP: Role of the prolyl isomerase Pin 1 in protecting against age-dependent neurodegeneration. Nature 2003;424: 556-561.

33 Balastik M, Lim J, Pastorino L, Lu KP: Pin1 in Alzheimer's disease: multiple substrates, one regulatory mechanism? Biochim Biophys Acta 2007;1772:422-429.

34 Luo GR, Chen S, Le WD: Are heat shock proteins therapeutic target for Parkinson's disease? Int J Biol Sci 2007;3:20-26.

35 Hartl FU, Hayer-Hartl M: Converging concepts of protein folding in vitro and in vivo. Nat Struct Mol Biol 2009;16:574-581.

36 Dou F, Netzer WJ, Tanemura K, Li F, Hartl FU, Takashima A, Gouras GK, Greengard P, $\mathrm{Xu} \mathrm{H}$ : Chaperones increase association of tau protein with microtubules. Proc Natl Acad Sci USA 2003;100:721-726.

37 Ali YO, Kitay BM, Zhai RG: Dealing with misfolded proteins: examining the neuroprotective role of molecular chaperones in neurodegeneration. Molecules 2010; 15: 6859-6887.

- 38 Uryu K, Richter-Landsberg C, Welch W, Sun E, Goldbaum O, Norris EH, Pham CT, Yazawa I, Hilburger K, Micsenyi M, Giasson BI, Bonini NM, Lee VM, Trojanowski JQ: Convergence of heat shock protein 90 with ubiquitin in filamentous alpha-synuclein inclusions of alpha-synucleinopathies. Am J Pathol 2006;168:947-961.

39 Falsone SF, Kungl AJ, Rek A, Cappai R, Zangger K: The molecular chaperone hsp90 modulates intermediate steps of amyloid assembly of the Parkinson-related protein alpha-synuclein. J Biol Chem 2009;284:3119031199.

40 Dickey CA, Kamal A, Lundgren K, Klosak N, Bailey RM, Dunmore J, Ash P, Shoraka S, Zlatkovic J, Eckman CB, Patterson C, Dickson DW, Nahman NS Jr, Hutton M, Burrows F, Petrucelli L: The high-affinity hsp90-chip complex recognizes and selectively degrades phosphorylated tau client proteins. J Clin Invest 2007;117:648-658.

41 Kang CB, Hong Y, Dhe-Paganon S, Yoon HS: Fkbp family proteins: immunophilins with versatile biological functions. Neurosignals 2008;16:318-325.
42 Goryunov D, Liem RK: Chip-ping away at tau. J Clin Invest 2007;117:590-592.

43 Pirkl F, Buchner J: Functional analysis of the hsp90-associated human peptidyl prolyl cis/ trans isomerases fkbp51, fkbp52 and cyp40. J Mol Biol 2001;308:795-806.

- 44 Carrello A, Allan RK, Morgan SL, Owen BA, Mok D, Ward BK, Minchin RF, Toft DO, Ratajczak T: Interaction of the hsp90 cochaperone cyclophilin 40 with hsc70. Cell Stress Chaperones 2004;9:167-181.

45 Osaka H, Wang YL, Takada K, Takizawa S, Setsuie R, Li H, Sato Y, Nishikawa K, Sun YJ, Sakurai M, Harada T, Hara Y, Kimura I, Chiba S, Namikawa K, Kiyama H, Noda M, Aoki S, Wada K: Ubiquitin carboxy-terminal hydrolase L1 binds to and stabilizes monoubiquitin in neuron. Hum Mol Genet 2003;12: 1945-1958.

46 Gong B, Cao Z, Zheng P, Vitolo OV, Liu S, Staniszewski A, Moolman D, Zhang H, Shelanski $\mathrm{M}$, Arancio $\mathrm{O}$ : Ubiquitin hydrolase Uch-L1 rescues beta-amyloid-induced decreases in synaptic function and contextual memory. Cell 2006;126:775-788.

47 Setsuie R, Wada K: The functions of Uch-L1 and its relation to neurodegenerative diseases. Neurochem Int 2007;51:105-111.

48 Barrachina M, Castano E, Dalfo E, Maes T, Buesa C, Ferrer I: Reduced ubiquitin c-terminal hydrolase-1 expression levels in dementia with Lewy bodies. Neurobiol Dis 2006;22:265-273.

49 Hall PA, Russell SE: The pathobiology of the septin gene family. J Pathol 2004;204:489-505.

-50 Peterson EA, Petty EM: Conquering the complex world of human septins: implications for health and disease. Clin Genet 2010; 77:511-524.

-51 Kinoshita A, Kinoshita M, Akiyama H, Tomimoto H, Akiguchi I, Kumar S, Noda M, Kimura J: Identification of septins in neurofibrillary tangles in Alzheimer's disease. Am J Pathol 1998;153:1551-1560.

52 Boutin C, Schmitz B, Cremer H, Diestel S: NCAM expression induces neurogenesis in vivo. Eur J Neurosci 2009;30:1209-1218.

- 53 Jin K, Peel AL, Mao XO, Xie L, Cottrell BA, Henshall DC, Greenberg DA: Increased hippocampal neurogenesis in Alzheimer's disease. Proc Natl Acad Sci USA 2004;101:343347.

54 Klementiev B, Novikova T, Novitskaya V, Walmod PS, Dmytriyeva O, Pakkenberg B, Berezin V, Bock E: A neural cell adhesion molecule-derived peptide reduces neuropathological signs and cognitive impairment induced by Abeta25-35. Neuroscience 2007; 145:209-224.

- 55 Neiiendam JL, Kohler LB, Christensen C, Li S, Pedersen MV, Ditlevsen DK, Kornum MK, Kiselyov VV, Berezin V, Bock E: An NCAMderived FGF-receptor agonist, the FGL-peptide, induces neurite outgrowth and neuronal survival in primary rat neurons. J Neurochem 2004;91:920-935. 